\title{
PENELUSURAN POA ISLAMISASI DI INDONESIA
}

\section{Muhammad Sueb}

Peneliti Islam Nusantara, alumni STF Driyarkara Jakarta

\section{PENDAHULUAN}

Jika ada pihak yang melontarkan klaim, bahwa terdapat Islam Historis di Indonesia, maka kemungkinan besar akan muncul banyak protes. Pasti, jika satu kebudayaan Islam disebut sebagai historis, maka ia akan menafikan historisitas keberislaman 'yang lain'. Apalagi dalam pluralitas keberislaman di tanah air, yang memang sejak awal islamisasi telah menunjukkan perbedaan, baik kultur geografi Nusantara maupun daerah 'luar' dimana Islam datang untuk melakukan konversi. Hanya saja, jika kita percaya akan adanya local genius, atau cultural core (inti pola kebudayaan) di sebuah masyarakat, maka pastilah terdapat satu 'ruh' kebudayaan yang menjadi kesatuan inti dari semua pluralitas tersebut.

Dari sinilah penggalian Islam Historis di Indonesia menjadi urgen. Kebutuhan ini berangkat dari satu postulat, bahwa keindonesiaan Islam kita telahlamamengalami proses dehistorisasi. Sebuah proses ketercerabutan akar baik kesejarahan, otentisitas kebudayaan, maupun genealogi keilmuan, yang membuat Keberislaman kita mengalami 'gagap' dalam menanggapi berbagai gelombang permasalahan yang datang dari luar. Dehistorisasi ini, seperti kita tahu merujuk pada dua gelombang islamisasi sejak abad ke-19 yang menemu ruang pada gerak Wahabisasi dan modernisasi. Ya, memang problematik, sebab Wahabisme sebagai klaimitas pemurnian Islam tentu memiliki 'niat suci' tersendiri, yakni pembersihan normativisme Islam dari berbagai laku akulturatif dengan kebudayaan lokal yang memang sering berasal dari peradaban pra-Islam. Sementara modernisasi, yang mengacu pada usaha rasionalisasi pemikiran keagamaan, bahkan mengklaim diri sebagai usaha menuju Islam Indonesia yang lebih maju. Artinya, jika Islam di Indonesia ingin menemukan bentuk keindonesiaan, maka ia harus melakukan rasionalisasi dari cara berpikir serba klenik, atau meminjam istilah al-Jabiri, 'rasionalitas yang irrasional', guna menemukan modernitas Indonesia. Kesejarahan Indonesia kemudian dipangkas, hanya pasca lahirnya negara-bangsa, sehingga yang dibutuhkan kemudian modernisasi. Sementara kesejarahan Indonesia yang berangkat dari pergulatan awal (islamisasi), bahkan dilihat sebagai 'remah-remah'(remnants) masa lalu yang harus dibabat, demi kecerlangan masa depan.

Fenomena ini mengambarkan terjadinya proses krisis identitas. Yakni sebuah proses dimana muslim Indonesia sudah tidak bisa lagi menyadari dan memahami apa permasalahan serta kebutuhan historis mereka. Jika kita mau konsisten, maka krisis identitas ini tidak saja dituduhkan pada proses Arabisasi yang mencerabut Islam klenik atas nama simbol kebudayaan masyarakat Arab, tetapi juga pada modernisasi. Semisal kasus modernisasi Orde Baru yang memaksa Islam harus non-ideologi, sehingga berbagai aspirasi politik Islam harus dibrangus 
kedalam "developmentalisme agama" dimana segenap partai dan ormas Islam tidak diperbolehkan lagi menyuarakan aspirasi keagamaan, tetapi lebih kepada penyediaan orientasi program ekonomi, atau bahkan sekadar menjadi suplemen legitimatif dari proyek pembangunan.

Mengikuti nasehat Snouck Hurgronje, Orde Baru kemudian membuat pemisahan antara Islam politik dengan Islam kultural, dan menaubatkan model kedua sebagai "Islam yang baik" karena tidak bermain pada tataran politik, tetapi bahkan telah menelorkan pembaruan pemikiran Islam, yang menggantikan terma ketidakadilan ekonomi akibat pembangunanisme, menjadi kebodohan masyarakat muslim akibat tradisinya. ${ }^{1}$ Dari sini pembelokan terjadi, karena kaum pembaharu kemudian menyediakan legitimasi bagi teologi pembangunan yang mensyaratkan tergantinya berbagai nilai tradisional, agar Islam mampu beradaptasi dengan modernitas.

Memang, kita sepakat bahwa Islam politik juga telah mencabut akar permasalahan kita dari historisitas Islam di Indonesia. Hal ini mungkin bisa kita lacak sejak para raja abad ke- 15 itu menulis berbagai historiografi tradisional, semisal Babad yang menciptakan sejarah, sesuai dengan kepentingan politiknya. Hal yang sama kita temukan pada geloran islamisasi negara modern, hingga berbagai partikularisme Islam politik, semisal Piagam Jakarta, penegakan syari'at Islam melalui Otonomi Daerah, hingga berbagai aksi kekerasan atas nama Tuhan. Geliat politik ini tentu saja telah menurunkan transendentalisme Islam sebagai agama, kedalam kepentingan kekuasaan yang tujuannya bukan lagi mencerahkan "jiwa-jiwa tertindas", tetapi merumuskan strategi Marxian: sejarah harus dipaksa agar sesuai dengan kepentingan politik kita! Umat Islam-pun terjebak dalam perjuangan simbolik dalam "membela Islam". Apa yang dibela sebenarnya ketakutan spiritual yang berangkat dari kedangkalan penghayatan agama, karena praktik hidup yang jauh dari mozaik spiritualitas a la "tasawuf Nusantara" yang bahkan sejak datangnya klaim otoritatif hukum Islam, ia dianggap sebagai penyimpangan. Hal ini yang kemudian melahirkan ketegangan antara agama dan kebudayaan, karena ketidakmampuan sebagian muslim untuk masuk kedalam dimensi esoteris dari Islam, padahal pergulatan kebudayaan, (dimana Islam normatif telah berpijak di pergumulan realitas masyarakat), adalah pergulatan makna, bukan lagi sekat-sekat simbolistik. Geliat Islam politik tidak hanya mencabut penghayatan keagamaan dari kelembutan spiritualitas, tetapi juga menjauhkan umat dari kesadaran akan permasalahan real yang dihadapinya. Berbagai pertanyaan, apakah jika syari'at ditegakkan melalui undang-undang, maka keadilan sosial akan terwujud? Apakah jika Negara Islam didirikan, kedaulatan hukum akan terlaksana? Berbagai tanda tanya ini tidak akan terjawab, karena pertaruhannya bukanlah ketertindasan nasib rakyat, tetapi egoisme ideologis yang entah apakah ada manfaatnya.

Diseberang lain, kita juga tak habis mengerti dengan segenap diskursus kontemporer yang dengan begitu mudahnya membawa isme-isme tertentu, semisal liberalisme Islam, neomodernisme Islam, fundamentalisme Islam, post-tradisionalisme, post-kolonialisme, dsb.

\footnotetext{
${ }^{1}$ B.J. Boland, The Struggle of Islam in Modern Indonesia, The Hague- Martinus Nijhoff, 1971, h., 149-152
} 
Tentu berbagai tipologi merupakan bukti bahwa pemikiran Islam kita begitu geliatnya. Inilah satu masa dimana "bom intelektual”" telah meledak, seperti yang diramalkan oleh Cak Nur. Satu ledakan yang tentunya membuat kita bangga, karena peradaban Islam telah mampu berkontestasi dengan kosmopolitanisme dunia modern. Hanya pertanyaan yang muncul adalah, apakah berbagai diskursus tersebut memang benar-benar sesuai dengan kegelisahan muslim Indonesia? Kenapa tiba- tiba saja sebagian muslim bersikap tidak toleran dengan "kaum non", sehingga wacana pluralisme begitu hegemonik, menjelma tema seminar dan perdebatan ilmiah, bahkan hingga otoritas "birokrat" Islam: MUI, turun tangan untuk memusnahkannya? Benarkah, ditengah situasi runtuhnya otoritarianisme negara, serta kearifan metodologis dari keilmuan Islam klasik, kita betul- betul terkungkung untuk berpikir, sehingga kebebasan pemikiran Islam menjadi satu-satunya kebutuhan kebudayaan kita? Jika gelora kebebasan atau liberalisasi itu hadir ke Indonesia, untuk menggempur fundamentalisme Islam, maka sejak kapan juga cara beragama kita menjadi demikian fundamental, padahal sudah sejak abad ke15, Islam Arab itu telah "bersetubuh" dengan tradisi Jawa-Sumatera? Berbagai fakta diskursif inilah yang membuktikan begitu dalamnya proses penutupan historisitas kebudayaan Islam kita, oleh segenap geliat kebangkitan Islam yang datang dari luar. Kita tentu bukan hendak lari dari perkembangan sejarah, dan ingin kembali pada masa lalu. Yang hendak kita sampaikan adalah, sebuah urgensitas pembongkaran struktur wacana, karena yang kita sebut sebagai historisitas bukanlah sebuah produk budaya otentik, tetapi sebuah pergulatan serta dialektika maknawi, yang terkonstruk, bukan oleh "paradigma luar", tetapi oleh cara berpikir masyarakat Indonesia, yang berangkat dari problem real-nya.

\section{ISLAM YANG DATANG}

Berangkat dari kegelisahan tersebut, maka penggalian kesejarahan akan dibidikkan kepada mekanisme islamisasi awal Nusantara, terkait dengan corak dari Islam yang datang ke tanah air, hingga proses "gelombangisasi" Islam tersebut, yang membentuk suatu pergulatan kebudayaan, dimana Islam dan tradisi Nusantara telah mengalami negosiasi kebudayaan, yang hadir hingga saat ini.

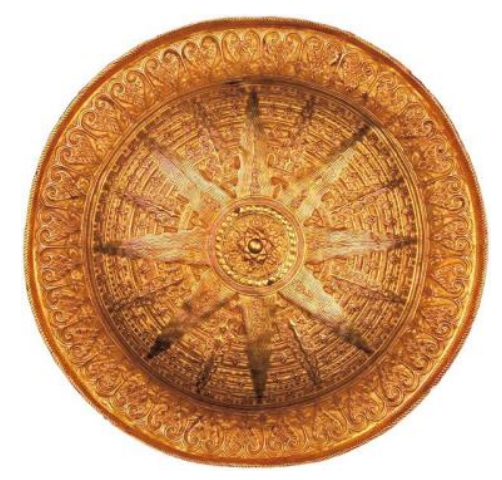

Meskipun benar bahwa Islam telah mulai menyebar di Nusantara ini padaabadpertama Hijrah, terbukti dengan tersebarnya para pedagang Arab yang melintasi perairan kepulauan kita. Hanya saja, bukti-bukti yang shahih masih belum didapatkan. Apalagi teori perdagangan yang mengisyaratkan motif ekonomi-politik, layaknya gagasan Van Leur banyak ditentang, jika 
dikatakan sebagai sebuah puncak islamisasi, karena meskipun memang para penguasa kerajaan (dalam hal ini pesisir) membutuhkan 'politisasi' Islam demi jaringan ekonomi internasional, namun motif ekonomi ini tidak bisa kemudian dijadikan kebudayaan utama islamisasi awal, karena ia mereduksi proses konversi agama pada tataran 'determinisme materialis'.

Kalau dikatakan batu-batu nisan abad ke-11 dan ke-13, baik di Sumatera maupun di Jawa Timur lebih memberikan kepastian, maka itupun benar, meski terdapat tesis yang menyatakan bahwa proses tersebut hanya mengindikasikan terjadinya pemukiman komunitas beragama Islam. Tidak ada jaminan bahwa saat itulah Islam berkembang. Hal ini bisa dilihat ketika pada waktu yang sama, batu nisan orang-orang Muslim juga didapatkan di Canton (Cina Selatan), tetapi Islam malah berkembang di Cina Timur. Apalagi beberapa tesis Orientalis yang kemudian dinamai teori 'khas Belanda', dimana beberapa peneliti semisal Snouck yang menyatakan terdapatnya tiga batu nisan Muslim paruh pertama abad ke-15 di Sumatera Utara, mengindikasikan persamaan dengan batu nisan Malik Ibrahim di Gresik (1418). Mengamini Van Ronkel, Snouck kemudian menyatakan bahwa batu nisan tersebut diimpor dari Cambay, Gujarat, yang oleh Moquette kemudian dijadikan argumentasi bahwa Islam Indonesia datang dari Gujarat. Hal yang sama terjadi pada penemuan nisan Malik al-Salih Pasai (1297) yang juga diperkirakan berasal dari wilayah India.

Satu anti-tesa pun tercipta, dimana segala teori kedatangan Islam dari batu nisan itu kemudian dibantah dengan satu justifikasi, bahwa imporisasi nisan hanya mengindikasikan terciptanya satu komunitas partikular serta terciptanya jaringan 'keluar' (yang dilatari oleh situasi perdagangan internasional), namun segenap proses tersebut belumlah dilihat sebagai puncak gelombang islamisasi, dalam arti penyebaran Islam yang telah menyeluruh kesegala lekuk peradaban masyarakat Nusantara. Islam baru bisa dikatakan berkembang, searah dengan proses pembentukan berbagai kerajaan Islam, yang pada tataran akademik kemudian melahirkan teori islamisasi 'jalur atas'. Berdasarkan pada bukti-bukti arkeologis (batu nisan Samudera Pasai), historiografi tradisional (semisal Hikayat Raja-Raja Pasai dan Sejarah Melayu), serta berita-berita asing (Marco Polo dan Ibn Batutah) dengan tingkat kepastian tinggi, dapatlah dikatakan bahwa kerajaan Islam telah berdiri di akhir abad ke-13 di ujung Sumatera. Tetapi pada waktu bersamaan, kerajaan Hindu-Budha yang terbesar dalam sejarah, juga berdiri di ujung Timur pulau Jawa: Majapahit. Perkembangan sejarah memperlihatkan bahwa Majapahit lah, bukannya Samudera Pasai yang tampil sebagai pemegang hegemoni politik terbesar pada abad ke-14. baru sejak pertengahan abad ke-15 sampai 16, Malaka telah Islam, tampil sebagai kekuatan maritim dan politik yang besar. Jatuhnya Malaka ke tangan Portugis seakan-akan membuka sumbat dinamika politik dan pemikiran Islam, sehingga dari abad ke-16 hingga 18, dengan abad ke-17 sebagai puncak, boleh dikatakan sebagai masa naik dan mekarnya pusat-pusat kekuasaan Islam di Nusantara. Dalam periode ini pulalah, proses islamisasi berbagai wilayah dan kesatuan etnis-kultural merupakan gejala umum, bukan fragmentaris.

Pada titik ini, maka diskursus Islam Historis di Indonesia akan beranjak pada corak umum atau watak kebudayaan Islam yang datang, untuk kemudian 'menyetubuh' kedalam 
struktur kebudayaan masyarakat Nusantara. Hal ini berangkat dari satu postulat, bahwa pengislaman Indonesia ternyata terjadi tanpa 'melukai' dan menghilangkan, bukan hanya simbol-simbol dari agama dan kepercayaan pra-Islam, melainkan bahkan antara unsur esoteris dari kedua belah pihak ternyata mengalami penyatuan yang bersifat substantif. Disinilah pandangan yang menyatakan bahwa islamisasi di Indonesia merupakan praktik konversi, digugat. Kenapa? Karena konversi mengindikasikan terjadinya proses penaklukan antara Islam universal, dengan agama 'lokal', dimana yang terjadi bukan sebuah dialog antara dua kebudayaan, melainkan ikonoklasme: penghancuran ikon budaya lokal oleh imperalisasi kebudayaan global. Dari sini maka proses islamisasi di Indonesia kemudian lebih tepat disebut sebagai proses adhesi, dimana antara Islam dengan agama pra-Islam mengalami proses dialog, yang mengakibatkan seorang Muslim Indonesia menjadi muslim, tanpa kehilang an akar tradisi keagamaan Hindu-Budha ${ }^{2}$. Bahkan secara radikal, terdapat tesis sinkretisme (khususnya di Jawa) yang menyatakan bahwa bukan Islam yang menaklukkan 'agama Jawa', tetapi struktur kebudayaan Jawa-lah yang 'memaksa' Islam untuk tunduk kepada sistem keyakinan yang mengacu pada mistisisme.

Berkaitan dengan hal ini, maka watak utama dari kebudayaan Islam yang datang dan 'menyetubuh' dengan kebudayaan Nusantara, yang akhirnya menjelma sebagai untaian sejarah intelektualisme Islam, bisa dipetakan sebagai berikut. Merujuk pada tipologi Prof. Taufik Abdullah, maka corak Islam yang datang ke Indonesia bisa dikarakterisasikan kedalam beberapa corak. Pertama, Islam mulai berkembang di Nusantara ketika agama ini telah 'lulus sensor' dalam menghadai beberapa peradaban besar: Persia, Hellenisme, Byzantium, dan India. Jadi, struktur kebudayaan Islam yang pada awal mula berasal dari Arab, telah mengalami proses mistikisasi sehingga mengacu kepada dua pembelahan bentuk : keindiaan Islam melahirkan model Islam popular (kerakyatan), sementara ke-Persiaan Islam melahirkan bentuk mistisisme Islam yang pada satu titik diadopsi oleh struktur kekuasaan.

Menarik kiranya tesis Woodward yang menggambarkan wilayah keindiaan Islam ini pada geo-kultural Kerala (India Selatan) yang berada di pantai Malabar. Setidaknya teks melayu Hikayat Raja-raja Pasai dan Sejarah Melayu mengaimini tesis ini. Struktur keislaman model ini ditemukan Woodward pada kesamaan karakteristik, antara kebudayaan muslim Kerala dengan muslim Nusantara, khususnya daerah pantai. Hal tersebut misalnya dapat dilihat dari kesamaan bentuk masjid yang terbuat bukan dari batu atau bata merah, melainkan dari kayu dengan 'tiga susun atap' Meru, seperti terdapat di Masjid Demak, masjid keraton Kota Gede, serta Imogiri Yogyakarta. Model masjid ini menjadi mainstream khususnya di Jawa, yang membuktikan sebuah proses Hinduisasi, dimana pembentukan masjid telah berangkat dari tradisi arsitektural kuil-kuil Hindu. Demikian juga organisasi sosial dan keagamaan yang berorientasi ulama (ulama-centric) seperti pesantren di Indonesia, dan madrasah di Kerala yang diarahkan pada hafalan dan pengulangan teks-teks klasik Arab serta penghormatan para wali, yang kebanyakan merupakan tokoh asli lokal. Kepemimpinan kyai juga terdapat di Kerala (disebut thangal) dimana kepemimpinan kharismatik ini kemudian digerakkan untuk

\footnotetext{
${ }^{2}$ Azyumardi Azra, Islam Nusantara, Jaringan Global dan Lokal, Bandung: Mizan, 2002, h., 20
} 
melaksanakan berbagai ritual kerakyatan semisal ziarah ke makam keramat, hidangan yang diberikan saat pelaksanaan ritual (di Jawa, selametan dan di Kerala, nercha) dengan bentuk makanan dari tepung beras (appem, appam). ${ }^{3}$ Sementara itu, asal Islam dari Deccan (India Utara) yang dipengaruhi oleh mistisisme Indo-Persia telah memberikan lambaran legitimasi religius bagi terbentuknya 'kepercayaan keraton' (royal cult) yang dimanfaatkan oleh para raja Melayu untuk menggantikan teokrasi Hindu kedalam konsep Raja-Sufi a la Islam.

Kedua, berbagai permasalahan teologis telah 'diselesaikan'. Patokan ortodoksi telah dibakukan, mazhab ahlus sunnah wal jama'ah telah ditentukan, nisbah antara kebebasan filosofis dengan batas-batas yang dibenarkan oleh kalam dan tasawuf telah ditetapkan oleh jumhur ulama. Ketiga, sejarah islamisasi dan pemikiran Islam di Nusantara bermula ketika 'dunia Hindu- Budha' sedang mengalami krisis, dan berkembang disaat dominasi ekonomi dan politik kolonialisme Barat berada di ambang pintu. Keempat, Islam mulai menyebar, ketika urf, kemungkinan terjadinya variasi lokal, telah pula merupakan bagian dari ketentuan yang diakui dalam kanon hukum Islam, tidak sekadar kenyataan yang terpaksa ditolerir. Dari sinilah tesis Abdurrahman Wahid tentang pribumisasi Islam menemu ruang. Yakni pada tersedianya kaidah pengembilan hukum Islam (qawa'idul figh dan ushul fiqh) guna mengakomodir kebutuhan hukum adat, melalui perumusan al-'adah al-muhakkamah. Akomodasi ini bukan merupakan proses Jawanisasi atau sinkretisme, karena hanya hal-hal yang bersifat furu'iyah yang terkait dengan adat lokal, yang diakomodir oleh peluang penafsiran nash, tanpa melakukan penggantian substansi ataupun aspek-aspek 'linguistik' dari kedua budaya, semisal pembacaan Barzanji yang tetap menggunakan bahasa Arab, agar tidak mengurangi aksentuase sastrawinya $^{4}$. Kesemua faktor historis ini membawa akibat pada corak pergulatan dan perenungan keagamaan, dan tentu saja situasi sosia-kultural yang dimunculkannya. Spekulasi teologis dan inovasi dalam masalah hukum telah dulu mendapatkan batas-batas baku, yang didukung oleh otoritas yang berlaku.

\section{'GELOMBANG' ISLAMISASI}

Dari proses pribumisasi yang telah melahirkan penerimaan antara tradisi Islam dan tradisi kenusantaraan ini, maka proses islamisasi bisa kita petakan dalam bentuk 'gelombang'. Dalam hal ini, gelombang islamisasi tidak mengacu pada usaha periodesasi yang dibatasi oleh tahun dan letak geografis, melainkan sebuah usaha penggalian dan penyambungan antara proses 'perubahan dan kesinambungan' (change and continuity) yang tergali melalui analisa sejarah berdasarkan 'sejarah mentalitas' (histoire de mentalite). Artinya, 'gelombang' ini merujuk pada gaya atau suasana kehidupan keagamaan yang tercipta dari pergulatan dialogis antara Islam dengan kebudayaan Nusantara. Dari niatan ini, maka gelombang islamisasi tersebut bisa dipetakan menjadi empat tahap yang beranjak dari proses puncak islamisasi, yakni sejak abad ke-16 hingga awal abad ke-19, dimana pergulatan Islam telah bersentuhan dengan kolonialisme dan modernisasi politik.

\footnotetext{
${ }^{3}$ Mark R. Woodward, Islam Jawa, Kesalehan Normatif versus Kebatinan, Yogyakarta: LKiS, 1999, h., 81-86

${ }^{4}$ Lihat Abdurrahman Wahid, Pribumisasi Islam, dalam Pergulatan Negara, Agama, dan Kebudayaan, Depok: Desantara, 2001, h., 19
} 


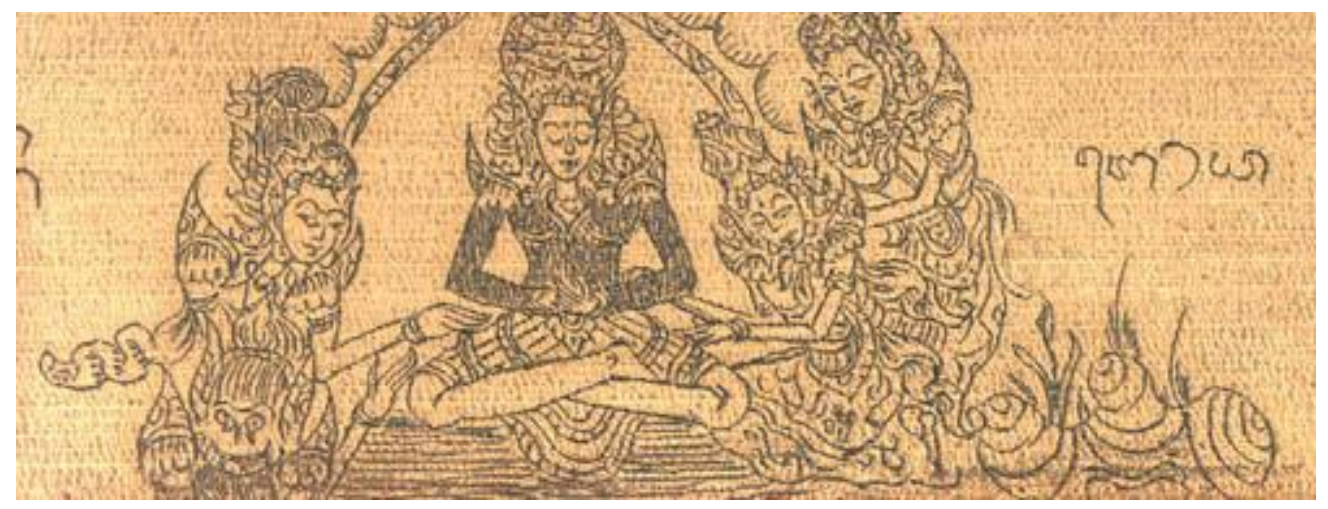

Gelombang pertama mengacu pada proses pengajaran awal atas syari'at dan akhlak Islam yang oleh Drewes disebut 'ortodoks', serta penciptaan batas tegas antara Islam dan dunia kafir yang harus ditinggalkan. Meskipun terjadi pada zaman yang berbeda dan berlangsung dalam jangka waktu yang tak sama, teks-teks tertua memperlihatkan bahwa kerihatinan religius yang paling awal dan yang mempunyai signifikansi sosial, adalah terbentuknya suatu komunitas pemeluk, yang bertolak dari pengakuan iman dan menyadari terdapatnya batas antara dunia kini yang haq dan dunia lama yang bathil. Meskipun memang, batasan ini masih cenderung bersifat furu'iyyah, semisal cerita lucu dari Hikayat Patani yang mengisahkan bahwa setelah raja dan keluarga istana masuk Islam (atas pengaruh ulama Pasai), mereka tidak lagi memakan babi, sementara kebiasaan yang lain tetap berjalan seperti sediakala. Jadi, batasnya sederhana, yakni hanya soal tidak makan babi !

Dalam gelombang ini pula diletakkan dasar-dasar kosmopolitanisme Islam, yakni sikap kultural yang menjadikan diri sebagai bagian dari masyarakat yang kosmopolitan dengan referensi kebudayaan Islam (universal). Inilah saatnya dimulai penerjemahan syair-syair pujaan kepada Nabi (barzanji) dan mitos-mitos Islam (dari Arab dan terutama Persia) ke dalam hikayat-hikayat Melayu dan dari Melayu ke bahasa Jawa, sudah sejak abad ke-15. Maka tidaklah mengherankan jika Sejarah Melayu melaporkan bahwa ketika para lasykar Malaka sedang beristirahat dalam menghadapi serangan Portugis (1511), mereka menghendaki agar dibacakan Hikayat Muhammad Hanafiah, supaya tercipta gelora heroisme yang berasal dari tokoh Persia tersebut. Jadi, jurang antara Nusantara dan Persia yang menganga oleh perbedaan budaya dan bahasa, ditiadakan, sehingga muslim Nusantara bisa merasakan kesatuan universal dengan kebudayaan Islam global tersebut. Inilah fase pertama islamisasi, dimana komunitas kafir harus ditiadakan, dan komunitas Islam harus dibina melalui satu 'pengangkatan kultural' tradisi Melayu kepada tradisi Islam.

Kecenderungan ini memang bisa terjadi, karena pada saat itu, konstruk persinggungan masyarakat Nusantara dengan kedatangan Islam, berada dalam proses interaksi perdagangan internasional, dimana Islam datang untuk menawarkan satu jaringan ekonomi kepada penduduk pesisir. Kosmopolitanisme tersebut kemudian terjadi. Hanya saja, ketika 'gelombang' tersebut sudah mulai merasuk ke wilayah pedalaman (pusat-pusat kekuasaan), maka konversi Islam kemudian berhadapan dengan tantangan baru, berupa 'dunia jahil' yang 
penuh dengan rimba mistis, dan mau tidak mau Islam harus menaklukkannya ${ }^{5}$. Ini berarti bukan saja domestikasi simbol-simbol keagamaan harus diadakan, tetapi pertanggungjawaban kultural tentang telah terjadinya peralihan agama, harus diberikan. Maka mitos konversi yang sekaligus merupakan pertanggungjawaban kultural dan legitimasi sistem dan landasan otoritas baru, tercipta pula. Disinilah kita temui mitos-mitos masuknya para raja kedalam Islam, semisal Mirah Silau yang menjadi Sultan Malikul Saleh, karena ia telah sanggup membaca syahadat dihadapan syeh Ismail yang sengaja dating dari Tanah Suci, dsb. Setiap kesatuan etnis-kultural dan pusat kekuasaan mempunyai mitos konversi yang juga berfungsi sebagai alat legitimasi. Jika Hikayat Raja-raja Pasai serta tarsila Sulu dan Manguidanao cenderung melihat penyebaran Islam sebagai landasan dari bermulanya pusat kekuasaan Islam, sementara Sejarah Melayu dan lontara Bugis-Makassar menunjukkan betapa pusat kekuasaan kafir dikonversi, maka Babad melukiskan tentang proses Islam yang bermula dari pinggiran pusat kekuasaan, dan akhirnya berhasil mengalahkan dan mengislamkan pusat tersebut.

'Gelombang' kedua ini sangat menentukan. Dalam suasana ini, islamisasi realitas juga mulai dijalankan. Islam dipakai sebagai prisma untuk melihat, memahami dan mengarahkan realitas sesuai dengan idealisme agama ini. Pusaka lama, yang animistik dan Hinduistik ditransformasikan ke dalam situasi pemikiran Islam dan tak jarang pula dipahami sebagai sesuatu yang Islami. Dari sudut doktrin, inilah saatnya ketika jurang (cleavage) antara agama sebagaimana dipahami masyarakat (folk religion) dengan agama sebagaimana teks-teks resmi mengajarkan (official religion), mulai menganga. Akan tetapi ini pula saatnya Islam mulai dirasakan sebagai bagian diri yang sah. Dalam situasi sosio-kultural ini, dua gejala yang saling berkaitan menjadi dominan. Pertama, perdebatan tasawuf tentang hakikat hubungan manusia dengan Tuhan, yang kemudian melahirkan satu pertarungan, bukan hanya pemikiran keagamaan, tetapi juga otoritas politik, semisal hukuman mati atas Siti Jenar oleh Walisongo, atau pembakaran besar-besaran kitab yang mengajarkan wujudiyah a la Hamzah Fansuri, oleh Nuruddin al-Raniri. Inilah masa awal, ketika sufisme heterodoks yang sebagian besar diambil dari mistikus Persia, semisal al- Hallaj, menginjakkan kakinya dibumi mistisisme Nusantara, dan mendapatkan tempat yang sangat istimewa, satu sisi dikarenakan kesamaan batiniyah dengan sistem kepercayaan pra-Islam, sisi lain karena Islam mistik ini sesuai dengan kepentingan segelintir eks-elite kerajaan Hindu seperti Majapahit yang menyimpan dendam atas hegemoni kerajaan Islam.

Teori mistifikasi Nusantara ini betul-betul menghegemoni pembacaan para peneliti terhadap proses islamisasi di kepulauan Melayu. Hal ini misalnya dilakukan melalui pembacaan mistis atas corak Islam yang datang dari India, dan kemudian dikotakkan dalam mazhab Syi'ah, sehingga meskipun mainstream mazhab muslim Melayu adalah Syafi'i, namun sejak awal konversi, corak Syi’i sudah melembaga, bahkan karena watak mistis dari masyarakat melayu. Unsur mistis yang berasal dari India ini biasa dirujukkan pada suatu sikap Gnostic terhadap nama-nama, mantera mistik, serta pemujaan terhadap orang suci yang merupakan peninggalan kultural dari ajaran Hindu (hermist). Jadi, antara Islam dengan

\footnotetext{
${ }^{5}$ Lihat Abdurrahman Wahid, Islam in Indonesia: Challenges and Future Prospects, 14 Maret 1985, h., 1-2
} 
kepercayaan Hindu-animistik saling 'bersetubuh' dengan proses peminjaman ritualisme yang sangat homogen. Sebagai misal, penghormatan terhadap orang-orang suci mengizikan pemberian sesaji di makam-makam para leluhur, pendiri kampung (danyang), penguasa, guru agama dan bahkan bebatuan serta pepohonan, seperti sesajen menyan yang oleh Islam dishahihkan oleh kesunnahan wewangian di beberapa makam para wali, atau tradisi ziarah para Raja Nusantara pasca-prosesi penobatan ke makam para raja terdahulu sebagaimana yang dilakukan para Sultan dari Perlak. Sementara itu, mengenai nama-nama dan mantera mistik, orang Melayu pada zaman Hindu memanggil roh-roh alam dan dewa-dewa dengan berbagai sebutan, yang mungkin agar suatu mantera tidak tersasar ${ }^{6}$. Pada era Islam, kesinambungan tradisi ini dilakukan melalui penyebutan semua asma Allah yang Mulia ketika berdoa, serta penggantian mantera Hindu Om dengan Kun (terjadilah), dan dengan Basmalah yang pengucapannya dapat menarik ikan dari semua lautan, membuat tanah gersang menjadi subur, menjatuhkan raja lalim, serta membawakan kehormatan dan keselamatan. Para guru orang Melayu itupun mengajarkan, bagaimana teks Arab yang tertulis dalam jimat pada waktu astrologi yang tepat, dalam air mawar, kenanga, cempaka, dsb.

Berbagai hal tersebut kemudian menandaskan satu tesis, akan ciri umum sistem kepercayaan orang Melayu yang merujuk pada ketiadaan rasa ortodoksi yang ekslusif. Hal ini terkhusus nyata dalam keagamaan Jawa, dimana para anggota keraton dan kaum terpelajar menyerap ide-ide Hindu dan Budhis Mahayana, penempatan kuil-kuil Hindu dan Budha yang berdiri berdampingan, serta penyebutan para raja sebagai 'Siwa-Budha', semisal Raja Hayam Wuruk (dimana islamisasi awal terjadi pada masa pemerintahannya) dipanggil 'Siwa-Budha dan 'Nirguana bagi pengikut Wisnu'. Dari sini, maka kita tidak begitu heran jika menyaksikan terdapatnya orang-orang elite abad ke-14 yang menganggap diri mereka Muslim, Budhis, dan Hindu sekaligus. Bagi orang Melayu, kedatangan Islam merupakan masukan energi gaib 'yang lain', yang bermanfaat bagi penguatan kesaktian era kegaiban Hindu. Pada titik inilah, beberapa tesis menyatakan bahwa kekuatan tasawuf dan thariqat dalam memegang tampuk kepemimpinan islamisasi Nusantara, terletak dalam kemampuannya memberikan sentuhan baru kedalam tradisi mistis, seperti kesaktian, pada masyarakat heterodoks Nusantara.

Proses mistifikasi Nusantara ini juga berlangsung melalui perumusan sistem otoritas serta landasan kekuasaan. Pada titik inilah teori kekuasaan yang bertolak dari pendekatan sufistik mulai dirumuskan. 'Negara' tidak sebatas refleksi dari kedirian sang raja tetapi juga pranata yang merupakan wadah bagi terwujudnya kesatuan harmonis antara raja dan rakyat, serta antara makhluk dan khalik. Dari sini lahir beberapa teks klasik tentang kenegaraan yang merupakan karya besar tentang teori kenegaraan Islam. Hal ini misalnya bisa kita lihat dalam Taj al-Salatain (Mahkota Segala Raja-raja) karya Buchari al-Jauhara pada 1603 di Aceh. Bertolak dari pemikiran sufistik dan ajaran moral politik, kitab ini sepenuhnya menempatkan dirinya dalam barisan teori kenegaraan Sunni tradisional. Hal ini kemudian memberikan kita pemahaman akan daya tarik Islam atas pola kekuasaan Nusantara, yang pada tataran teokratis

\footnotetext{
${ }^{6}$ R.O. Winstedt, The Malays: A Cultural History, London: Routledge \& Kegan Paul PLC, 1947, h., 161-162
} 
merujuk pada konsep Islam tentang tradisi martabat raja Persia, yang akan terlihat nanti, diasimilasi dari Islam abad pertengahan.

Digunakannya tradisi Islam abad pertengahan yang menyangkut martabat raja oleh orang Melayu, dinyatakan secara jelas sekali dalam pemakaian gelar-gelar dari raja Muslim yang terkena pengaruh Persia. Raja-raja Melayu sering memakai gelar Muslim segera setelah mereka memeluk Islam. Merah Silu, raja Pasai, sewaktu beralih ke agama Islam menerima gelar Arab, yakni Sultan, dan dalam suatu sidang para pimpinan dan rakyatnya menyatakan Merah Silu sebagai 'Bayang-Bayang Tuhan di Bumi' (zill Allah fil Ardl). Gelar-gelar semacam ini juga ditunjukkan pada mata uang. Mata uang Malaka abad ke-15, misalnya, menyatakan sultan yang memerintah sebagai Syah, serta 'Penolong dunia dan agama' (Nashir al-dunya wa al-din). Sebuah laporan dari portugis mengenai Pasai abad ke-16 mengemukakan bahwa rakyat di negeri itu percaya bahwa raja adalah 'orang yang memerintah di bumi sebagai wakil Tuhan'. Tema ini dikembangkan secara seksama dalam berbagai karya tulis Melayu, seperti Sejarah Melayu yang mengungkapkan, seorang pangeran yang adil akan bersama-sama dengan Nabi, sehingga keduanya membentuk 'dua permata pada satu cincin'. Demikian juga naskah-naskah semisal Undang-undang Pahang, dan Taj al-salatin, juga mencari dukungan dari al-Qur'an guna legitimasi para raja, meskipun kitab suci ini tidak selalu kondusif bagi sebuah legitimasi absolutisme raja, ditambah dengan beberapa penafsiran orang-orang Melayu tersebut yang sering melewati batas, seperti penerjemahan surat XI: 30, "Bukannya Tuhan menempatkan Adam di bumi sebagai wakil-Nya, melainkan Dia telah menempatkan raja di bumi ini sebagai wakil-Nya”.

Harus diakui fakta yang menyakatan bahwa Islam memiliki perlengkapan ideologis yang mendukung martabat raja Melayu, sepintas lalu nampak mengherankan dan kontradiktif. Dalam ajaran Islam, banyak hal yang mengesankan diterimanya Islam akan berkonsekuensi penentangan terhadap basis kekuasaan yang berpusat pada raja. Bentuk pemerintahan Melayu, sangat berbeda dengan citra sebuah komunitas yang diatur oleh syari'at. Kepemimpinan Nabi Muhammad secara tegas juga menyatakan bahwa kekuasaan tertinggi berada 'ditangan' Allah, bukan pada individual penguasa. Hanya saja, sejarah juga mencatat terjadinya 'penyimpangan' absolutisme penguasa tersebut, khususnya yang terkonstruk dalam periode abad pertengahan, dimana suatu komunitas yang didasarkan pada syari'at hanyalah salah satu cita-cita politik dunia Islam. Cita-cita yang lain dan penting adalah visi yang diilhami oleh Persia, berupa sebuah masyarakat yang diartikulasikan di sekitar lembaga 'martabat raja'.

Pengaruh Persia pertama-tama nampak dalam perkembangan lembaga khalifah yang sebenarnya bermula sebagai lembaga biasa (bukan lembaga raja), namun akhirnya mengambil sebuah karakteristik monarki Persia, khususnya masa rezim Abbasiyah yang berbasis di Baghdad, tidak jauh dari jantung Kerajaan Persia lama. Paham-paham Persia mengenai 'penguasa kosmis' yang kehadirannya menciptakan suasana damai, mendorong timbulnya sejenis khalifah Islam yang baru. Julukan dari Babylonia lama, 'Bayangan Tuhan di bumi', ditujukan kepadanya, dan 'cahaya kenabian' konon bersinar di sekeliling dahi khalifah itu. Kemudian pada periode Abbasiyah di dunia Islam berkembang suatu Khalifah Kerajaan yang 
langsung menggantikan martabat raja iran pra-Islam. Namun pada saat Islam diadopsi di wilayah Melayu, kepemimpinan spiritual dan politik di dunia Muslim telah berhenti menjadi monopoli satu khalifah. Khalifah Baghdad hanya salah satu monarki dalam Islam yang dipengarhui Persia. Dalam abad ke-11, oarng-orang Saljuq menggunakan sebuah gelar yang baru dan kuat yakni Sultan yang juga mendapatkan gelar zillu Allah fil Ardl. Belakangan dalam abad tersebut, di India, Sultan-sultan Delhi memperkenalkan kewajiban sujud di depan raja. Tidak lama kemudian, para penguasa Benggala kemudian mengikuti cara orang-orang Saljuq dengan menggunakan gelar Persia yang lama, yakni Shah, dan menamakan diri mereka khalifah. Jadi, pada masa menjelang islamisasi di Nusantara terdapat perluasan galaksi sultansultan Muslim yang mengalami Persianisasi, serta menjalankan peran yang tidak jauh berbeda dengan raja Melayu pra-Islam. Para Mullah yang menyertai saudagar Muslim ke Pasai atau Malaka, tentunya telah membawa berita mengenai perkembangan tersebut, dan dalam dunia yang semakin didominasi oleh Islam, maka adalah menggoda dan tidak merugi jika raja-raja Melayu kemudian melihat dirinya sebagai anggota galaksi Muslim tersebut.

Ciri Islam lainnya yang menarik hati para raja Nusantara adalah sufisme, atau mistisisme yang pada tataran politik telah memberikan legitimasi besar bagi terbentuknya kekusaan. Pada titik inilah kritik A.H. Johns menemu ruang. Yakni pada pernyataan yang menunjukkan bahayanya menafsirkan islamisasi hanya dalam pengertian politik atau perdagangan, karena dokumen-dokumen Melayu maupun Eropa menunjukkan bahwa masalah-masalah spiritual merupakan urusan kenegaraan yang penting bagi raja di wilayah Nusantara. Kewajibannya adalah memperoleh pengetahuan mengenai doktrin-doktrin atau teknik spiritual terbaru dan menggunakannya demi manfaat rakyat. Sama seperti raja pra-Islam yang digambarkan sebagai seorang bodhisatwa, yang memperhatikan kesejahteraan spiritual rakyatnya, raja-raja Nusantara di kemudian hari bahkan memanggil para misionaris Kristen untuk membahas 'dunia mendatang' bersama mereka.

Doktrin mistik khusus yang nampak telah menawan perhatian Raja-raja Nusantara selama masa awal islamisasi adalah doktrin Manusia Sempurna (Insan Kamil). Satu fakta yang memperlihatkan bahwa pada saat itu, masyarakat Nusantara sudah mengenal karya ahli mistik abad ke-15, Abd al-Karim al-Jilli (meninggal 1417 M), serta pendahulunya pada abad ke-13, Ibn 'Arabi (1165-1240 M). Hal ini bisa kita lihat pergulatan pemikiran tasawuf di Nusantara abad ke-16, khususnya di wilayah Sumatera yang secara spesifik terlibat dalam perdebatan mengenai doktrin Insan Kamil tersebut ${ }^{7}$. Dalam hal ini, minat para raja Nusantara pada Manusia Sempurna, makhluk suci yang telah sepenuhnya mencapai kesatuannya yang pokok dengan tuhan, dan yang bagaikan bodhisatwa, membimbing para muridnya untuk mengikuti jalan yang ditempuhnya, secara bertahap muncul dalam catatan-catatan mengenai dunia Melayu bada ke-15 dan 16. Kronika Pasai, Hikayat Raja-raja Pasai, secara tidak langsung mengemukakan bahwa seorang raja Pasai abad ke- 14, memperoleh kekuatan magis karena menjadi Muslim. Indikasi lebih lanjut mengenai minat Raja Melayu pada Manusia Sempurna

\footnotetext{
${ }^{7}$ A.C. Milner, Islam dan Martabat Raja Melayu, dalam Ahmad Ibrahim, Sharon Siddique, dan Yasmin Hussain (ed) Islam di Asia Tenggara, Perspektif Sejarah, Jakarta: LP3ES, h. 63-65,
} 
dapat ditemukan dalam Malay Annals, dimana Sultan Mansur (1456-77) sangat terkesan oleh Maulana Abu Bakar, seorang murid Maulana Abu Ishak, yang menurut naskah itu, sangat mahir dalam mistisisme atau tasawuf., seperti yang termaktub dalam bukunya, Durr Mandzum yang selalu bisa memberikan jawaban-jawaban esoteris atas berbagai pertanyaan ortodoks sang raja.

G e 1 o $\mathrm{m}$ b a n g' ketiga mengacu pada arah ortodoksi yang menuntut keselarasan antara keyakinan agama dengan tata kehidupan sosial dan pribadi, telah semakin intens. Keprihatinan fiqh makin bertambah kuat dengan usaha kearah terhapusnya segala macam khurafat. Berbagai cara dipakai

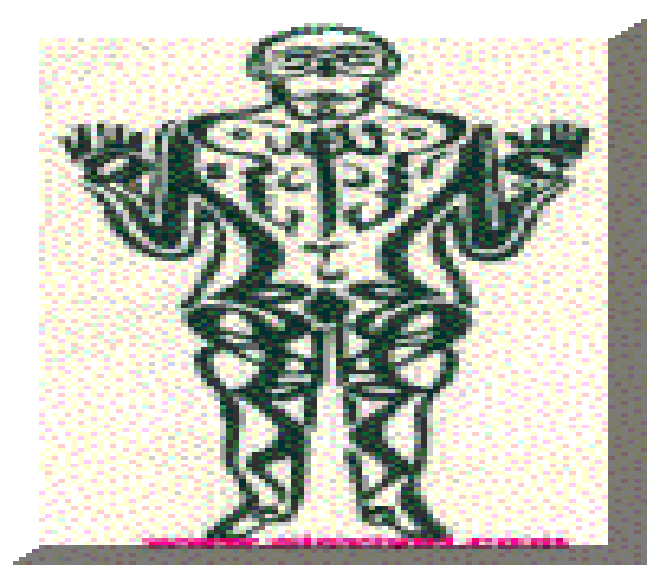

untuk menyesuaikan kecenderungan folk religion kedalam keharusan official religion semisal gerakan Padri yang dipengaruhi Wahabisme, Kemas Fachruddin dan para ulama istana Palembang yang menulis kitab-kitab, yang tidak saja meneguhkan keberlakuan syariah, tetapi juga menyerang segala kecenderungan yang bersifat syirik. Proses ini ditambah dengan semakin menguatnya otoritas keraton dalam menetapkan hukuman atas dominasi syari'ah kepada mistisisme, dimana para raja yang secara politis telah mengadaptasi teori raja-sufi, memiliki kepentingan, baik pusat kekuasaan syari'ah yang memiliki kewajiban untuk mendisiplinkan kecenderungan sufisme heterodoks semisal kasus Kyai Mutamakkin dengan Amangkurat $\mathrm{IV}^{8}$, maupun para raja mistik wilayah pedalaman yang tidak ingin tersaingi keilahian rajawinya, oleh para wali mistis, seperti penghukuman Sultan Agung atas murid Siti Jenar, Syeh Amongraga 9 .

Pada titik ini, gerakan 'pemurnian' tasawuf berkembang. Di Sumatera, Nuruddin alRaniri menghapuskan sufisme-pantheistik milik Hamzah Fansuri dan Syamsuddin alSumaterani, yang pada era Iskandar Muda I (Aceh) menjadi mazhab resmi negara. Penghapusan tersebut tidak sebatas pembrangusan 'pemikiran keagamaan' melainkan juga politik, dimana al-Raniri melakukan pembakaran kitab-kitab yang mengajarkan doktrin

\footnotetext{
${ }^{8}$ Zainul Milal Bizawie, Perlawanan Kultural Agama Rakyat, Pemikiran dan Paham Keagamaan Syekh Ahmad al-Mutamakkin, Ciputat: Yayasan Keris, 2002, h., 34

${ }^{9}$ Lihat, Centhini, Tambangraras-Amongraga, Ngabei Ranggasutrasna, dkk, jilid I, Jakarta: Balai Pustaka, 1991, h., 26
} 
wujudiyah, sekaligus pembunuhan massal atas para pengikutnya ${ }^{10}$. Satu hal yang kemudian dikritik oleh Abdur Rauf al-Singkili yang meskipun menggerakkan Sunnisme, salah satunya melalui permintaan terhadap ulama Mekkah untuk menulis kitab yang menekankan syari'ah, namun tidak setuju dan mengecam aksi pembunuhan al-Raniri tersebut. Kasus serupa juga digerakkan oleh Syeh Syihabuddin Palembang, yang selama karir spiritualnya dihabiskan untuk menentang ajaran martabat tujuh, varian lain dari wahdatul wujud.

Di Jawa, proses ortodoksi ini di lakukan para Walisongo yang mengembalikan praktik mistis dalam Islam kepada jalan syari'ah. Jadi, para wali bukan kemudian anti-mistisisme, melainkan watak dan arahnya lebih kepada pembentukan akhlak dan penataan syari'ah umat, sebagaimana termaktub dalam sufisme al-Ghazali. Hanya saja, konstruk politik pertarungan ini memberikan gambaran pertarungan kekuasaan yang bisa dikatakan lebih besar dibanding luar Jawa. Hal ini dikarenakan sejak awal, Islam di Jawa telah terdikotomi dalam pesisiran vis a vis pedalaman. Penyimpangan yang dilakukan Siti Jenar kemudian diidentikkan dengan gerakan latent mantan petinggi Majapahit-Hindu (Kebo Kenongo) yang hendak membalas dendam melalui pemanfaatan mistisisme Islam a la Siti Jenar. Proses ini terjadi dalam perkembangan berikutnya, dimana imperium syari'at Jawa pesisir yakni kesultanan (kesunanan) Giri yang menjadi otoritas spiritual sekaligus dominasi armada pelabuhan, tidak hanya menancapkan syari'atisasi dari kecenderungan mistik sinkretis kaum keraton pedalaman, tetapi juga menggerakkan hegemoni politik. Hal ini wajar, mengingat struktur sosial masyarakat pesisir tidak membutuhkan otoritas pedalaman dikarenakan jaringan mereka yang lebih berorientasi pada perdagangan internasional. Dari jaringan global inilah, masyarakat muslim pesisir menjadi lebih rasional, tetapi juga ortodoks ${ }^{11}$ dikarenakan kemudahan syari'at untuk masuk, tanpa dihalangi oleh kebudayaan Hindu-animistik seperti yang melembaga dalam Islam pedalaman. Hegemoni Giri Kedaton ini berlangsung hingga penaklukan Mataram Islam pada tahun 1624, dimana otoritas pedalaman ini hendak mengembalikan kejayaan 'Jawa Hindu', serta melakukan pemisahan antara penyatuan otoritas spiritual (Sunan) dan politik (Sultan) dalam diri Wali yang ada di pesisiran, untuk kemudian direbut oleh penguasa Mataram dengan menyematkan gelar Sunan pada dirinya, sekaligus permintaan gelar Sultan dari Mekkah (1641) sebagai usaha penyatuan mistis antara kesunanan dan kesultanan dalam diri seorang raja ${ }^{12}$ Proses peminggiran kekuasaan pesisiran serta otoritas syari'at para ulama tersebut menemu puncak tragisnya pada pembantaian ribuan ulama oleh Amangkurat I pada 1647.

'Gelombang' ketiga ini juga ditandai oleh mulai menyebarnya pesantren yang terlibat dalam pergulatan ortodoksi ajaran. Disaat ini pula tradisi dan silabus keilmuan pesantren mulai terbentuk, mendampingi munculnya kelahiran para ulama besar Nusantara abad ke-18 yang

\footnotetext{
${ }^{10}$ Alwi Shihab, Islam Sufistik: Islam Pertama dan Pengaruhnya Hingga Kini di Indonesia, Bandung: Mizan, 2001, h., 48

${ }^{11}$ Dalam hal ini, watak ortodoks dari Islam Jawa pesisiran tidak kemudian menghilangkan corak mistis didalam dirinya. Dua buah manuskrip abad ke- 16 yang berisi ajaran-ajaran mistik masih ada, karena manuskrip tersebut dibawa oleh ekspedisi Belanda pertama ke Indonesia (1595-97). Kedua manuskrip itu meungkin berasal dari pantai utara Jawa dan keduanya merupakan mistisisme ortodoks, meskipun salah satu diantaranya, yakni Peringatan-peringatan dari Syeh Bari, berisi peringatan yang panjang lebar terhadap berbagai bid'ah, yang kmeudian memberikan kesan bahwa bid'ah bukan hal yang tidak lazim disana. Lihat M.C. Ricklefs, Islamisasi di Jawa, h., 77

12 Sultan Agung berhasil menaklukkan Giri dengan menempatkan lasykarnya dibawah pimpinan putera raja independen terakhir dari Surabaya (ditaklukkan Sultan Agung pada 1625) yang berkaitan dengan keluarga Sunan Ampel, wali senior dari Sunan Giri. Lihat Irsyad Zamjani dan Muhammad Faishal A, Islam Jawa Pesisir (an): Sekadar Teorisasi Sejarah, jurnal Tashwirul Afkar, Edisi No. 17/2004, Jakarta: Lakpesdam, h., 121-122
} 
telah menciptakan jaringan ulama jawi dan membawakan misi pendisiplinan syari'ah beserta ilmu alat-nya, semisal tafsir, hadist, dan tentu saja fiqh. Hal ini misalnya dilihat Abdurrahman Wahid sebagai 'barokah' dari terbentuknya usaha ekonomi kerakyatan seperti kebun teh, tembakau, dan kopi, selain pabrik gula milik kolonial, yang mambuat muslim pribumi memiliki modal finansial untuk menyekolahkan para putranya ke luar negeri, yakni ke Mekkah. Sebagaimana kosmologi Jawa pesisiran, pusat kosmis dari Islam area ini bukanlah terletak pada elitisme keraton layaknya Islam Jawa pedalaman, melainkan pada Mekkah, dimana sumber keilmuan ortodoksi Islam tertancap dengan kuat ${ }^{13}$. Kedatangan para santri Nusantara, dimana terbukanya Terusan Suez yang membuka pelayaran motor antara Hindia Belanda dan Eropa, telah membuahkan tradisi Islam baru kearah pembakuan berbagai korpus keilmuan yang berorientasi pada syari'ah.

Lahirlah jaringan ulama Jawi itu, yang diwakili oleh para kyai (calon) pendiri pesantren seperti Kyai Abdul Ghani Bima, Kyai Arsyad Banjar, Kyai Abdus Shomad Palembang, Kyai Hasyim Asy’ari, Kyai Khalil Bangkalan, serta dua maha guru, Kyai Nawawi Banten dan Kyai Mahfudz Tremas. Dalam hal ini, dua nama besar: Kyai Nawawi Banten dan Kyai Mahfudz Tremas merupakan dua guru besar dari Jawa Timur dan Barat yang menjadi kiblat kelimuan Islam internasional, serta menetap di Mekkah-Madinah. Segenap kyai pendiri pesantren, merupakan jajaran santri dari kedua ulama ini, yang kemudian membentuk barisan ulama Sunni ${ }^{14}$. Dalam perkembangannya, para ulama ini kemudian tidak hanya menciptakan proses ortodoksi atas corak keilmuan mistis abad ke-18, namun terlebih telah melahirkan sebuah sintesa antara fiqh dengan tasawuf, yang oleh Abdurrahman Wahid disebut sebagai fiqh-sufistik. Disinilah bisa kita lihat seorang Kyai Bisri Syamsuri yang merupakan 'kyai fiqh' tetap memiliki kegemaran untuk membedah berbagai keilmuan akhlak sufistik semisal kitab Qathr al-Ghaits, Al-Nasha'ih ad-Diniyah Bidayat al-Hidayat, dsb. Kecenderungan untuk tidak meninggalkan sama sekali sufisme ini kemudian dilambari oleh pembaruan pada tataran metodologi keilmuan Islam, sehingga silabus dan pemikiran Islam di pesantren sangat memperhatikan ilmu 'alat seperti tafsir, hadist, ushul fiqh, balaghah, manthiq, dst ${ }^{15}$

Pada 'gelombang' ini, proses institusionalisasi sufisme juga mulai terbentuk dan menyebar. Kecenderungan sufisme yang bersifat pribadi, seperti syair-syair wujudiyah Hamzah Fansuri, telah diganti dengan ordo-ordo tarekat yang tentu saja pada tataran intelektualisme, telah mengakibatkan mundurnya geliat pemikiran tasawuf ${ }^{16}$. Hal yang agak

\footnotetext{
${ }^{13}$ Irsyad Zamjani dan Muhammad Faishal A, Islam Pesisiran, h., 118

${ }^{14}$ Lihat Abdurrahman Mas’ud, Intelektual Pesantren, Yogyakarta: LKiS, 2004, h., 92

15 Dari sini Gus Dur kemudian mengambil kesimpulan bahwa 'pemurnian' syari' at yang dilakukan para ulama pesantren abad ke-19 tersebut, bukanlah sebuah Wahabisasi yang murni menghilangkan aspek sufisme dalam Islam. 'Pemurnian' tersebut lebih kepada syari'atisasi tasawuf sehingga muncul model keislaman yang ia sebut sebagai fiqh-sufistik. Jadi, hal ini merupakan kesinambungan dari gelombang pertama islamisasi yang menekankan pada tasawuf dan tarekat, yang oleh ulama Nusantara- Mekkah tersebut diperhalus oleh kuatnya disiplin fiqh, serta kekayaan keilmuan bahasa, sastra, tafsir, dan segenap ilmu metodologi Islam. Lihat Abdurrahman Wahid, Asal-Usul Tradisi Keilmuan di Pesantren, dalam Menggerakkan Tradisi, Yogyakarta: LKiS, h., 164-166

16 Taufik Abdullah, Pemikiran Islam di Nusantara dalam Perspektif Sejarah, Sebuah Sketsa, jurnal Prisma 3, Maret 1991, Jakarta: LP3ES, h., 21
} 
berbeda dengan perkembangan di Jawa, dimana surutnya kontroversi tasawuf falsafi milik mistikus heterodoks, yang ditandai dengan kematian Siti Jenar dan para muridnya, telah membuahkan berbagai suluk Jawa. Tradisi suluk ini merupakan perpaduan kembali antara tasawuf dengan mistik Kejawen, yang kemudian melahirkan kebangkitan sastra Jawa menjelang abad ke-19 ${ }^{17}$. Pada titik ini, proses penyebaran tarekat di Indonesia, sering dilihat berawal dari 'atas', yakni di lingkungan istana dan lama kmeudian barulah merembes ke kalangan masyarakat awam. Para pengarang sufi Sumatera bekerja di bawah lindungan kerajaan. Kronika berbahasa Jawa, dari Cirebon dan Banten menceritakan bagaimana pendiri dinasti raja, mengunjungi tanah Arab dan berbai'at menjadi pengikut sejumlah tarekat. Dalam hal ini keberadaan tarekat dipandang sebagai sumber kekuatan siritual, sekaligus melegitimasi dan mengukuhkan posisi raja.

Menjelang abad ke-18, berbagai tarekat telah memperoleh pengikut yang tersebar di Nusantara. Orang-orang yang baru kembali dari Mekkah dan Madinah menyebarkan tarekat Syattariyah, sebuah tarekat 'ajaran' Al-Qusyasyi dan Al-Kurani yang menyatukan tradisi intelektual sufi India dan Mesir. Tarekat ini merupakan tarekat paling popular, pertama di Indonesia, dan paling mudah melakukan pribumisasi karena wataknya yang mistis, semisal gagasan martabat tujuh dalam kitab Tuhfah karya Al-Burhanpuri yang sangat digemari oleh masyarakat awal Nusantara. Selain tarekat ini, terdapat Qadiriyah wan Naqsyabandiah serta Naqsyabandiah Khalidiyah yang memiliki pengaruh besar. Pemeluk berbagai tarekat tersebut tidak hanya menyebarkan wirid dan ritual ketuhanan, melainkan juga praktik kesaktian seperti yang terdapat dalam kultus kekebalan tubuh atau debus di Aceh, Minangkabau, Banten, Cirebon, dan Maluku ${ }^{18}$ Dalam perkembangannya, tarekat-tarekat ini telah menjelma media perlawanan vis a vis kolonialisme, seperti gerakan tarekat Sammaniyah di Palembang yang melawan Belanda pada 1819 melalui kekuatan ekstase dzikir, atau pemberontakan petani Banten (1888) oleh tarekat Qadiriyah wan Naqsyabandiah, dsb.

Proses ortodoksi, situasi kontroversi, konsolidasi tradisi pesantren dan institusionalisasi thariqat tersebut berlangsung disaat terjadinya birokratisasi agama. Semua peristiwa pemikiran keagamaan ini terjadi ketika otoritas keagamaan makin diikatkan pada kekuasaan politik. Ketika para ulama dan pesantren mereka semakin berhasil memperluas lingkaran keberlakuan patokan moral dan hukum keagamaan, kekuasaan makin bertumpu pada keraton yang telah berada dibawah dominasi kolonialisme asing. Hal ini bukan saja dapat menjadikan pesantren dan ulama sekali-kali bisa tampil sebagai kritikus yang keras terhadap situasi sosial yang diciptakan oleh hubungan kolonial, tetapi juga, dan lebih penting, makin peka terhadap tarikan kosmopolitanisme kultural Islam: suatu kecenderungan yang didalam 'gelombang' kedua telah diperlakukan sebagai sesuatu yang lumrah. Afinitas antara keharusan berlanjutnya proses ortodoksi dengan kepekaan terhadap situasi pemikiran dan politik dunia Islam lain, terjalin

\footnotetext{
${ }^{17}$ Ann Kumar, The Diary of a Javanese Muslim, Religion, Politics and the Pesantren 1883-1886, Australia: The Australian National University Printery, 1985, h., 17-19

${ }^{18}$ Martin van Bruinessen, Kitab Kuning, Pesantren dan Tarekat, Bandung: Mizan, 1999, h., 196-197
} 
dengan erat ${ }^{19}$ Afinitas ini sekaligus merupakan jawaban terhadap permasalahan kolonialisme dan keterbelakangan umat. 'Gelombang' keempat hadir di ambang pintu.

Di awal perkembangannya, wajah politik dari afinitas ini cenderung bercorak pan-Islamis: hasrat untuk menciptakan suatu komunitas politik Islam yang bercorak global. Tak lama kecenderungan ini berlanjut. Bahkan di Indonesia, tak lebih dari secercah kerlingan mata yang segera terlupakan. Namun, secercah itu berhasil menumbuhkan mitos yang kuat tertancap dalam benak para perumus politik kolonial. Pada titik ini, kosmopolitanisme Islam yang ortodoks semakin berhasil merumuskan identitas diri dan hasrat-hasrat normatif yang ingin dicapai. Modernisme Islam lahir, dan kontroversi kaum tua dengan kaum muda yang segera dimasukkan dalam 'kotak' 'tradisionalis' vis a vis 'reformis-modernis' terjadi, melambari konflik terbaru pasca perang tafsir antara mistisisme dengan syari'ah.

Terlepas dari klaim non-politik gerakan reformis ini, 'gelombang' keempat merupakan benih dari situasi dilematis dimana umat Muslim sedang merasakan kebangkrutan dunia Islam, disatu sisi, dengan hegemoni Barat disisi lain. Karakteristik yang paling signifikan dalam proses ini adalah penerjemahan pengalaman dan observasi politik ke dalam renungan keagamaan. Karena itulah, disamping melanjutkan proses ortodoksi, yakni 'pemurnian' keagamaan yang telah beranjak dari Wahabisme, dan lebih tergerak dalam rasionalisasi dan modernisasi a la Muhammad Abduh, dimana mistisisme harus dibubarkan demi rasionalisasi agama plus adaptasi manajerial berbagai lembaga pendidikan Barat, demi kemajuan umat Islam, maka 'gelombang' inipun menggambarkan sebuah ideologisasi Islam, yang memiliki resiko penempatan Islam sebagai landasan sistematis dari strategi sosio-politik. Dalam kaitan inilah sikap terhadap ajaran dan hukum Islam mau tak mau menjadi fokus utama perdebatan. Inilah saatnya tuntutan terhadap dibukanya 'pintu ijtihad' diajukan, dan keberlakuan sistem otoritas tradisional dipermasalahkan. Jadi bisalah dimengerti jika masalah-masalah khilafiyah digugat, sehingga dengan menggugat tradisi keagamaan, sistem otoritas tradisional dijadikan tidak fungsional. Seruan 'kembali ke al- Qur'an dan Hadist' sekaligus ingin diartikan sebagai pembebasan dari himpitan tradisi dan perumusan strategi baru menghadapi dunia Barat, serta sebagai usaha penyelesaian keterbelakangan umat.

19 Taufik Abdullah, Pemikiran Islam, h., 23 